\title{
OPEN PUBLIC SPACES OF KYIV IN THE CONTEXT OF SOCIO-SPATIAL APPROACH
}

\author{
${ }^{1}$ Natalia MEZENTSEVA, ${ }^{2}$ Maria PALCHUK \\ Taras Shevchenko National University of Kyiv, Ukraine \\ provotarnat@ukr.net, ${ }^{2}$ marialookhere@gmail.com
}

\begin{abstract}
Urban public spaces determine the identity of the city's dwellers, ensure the implementation of the communication function. They are constantly changing, characterized by various transformational processes that take place under the influence of various factors in the development of the city. The need for knowledge of contemporary complex and ambiguous processes in cities causes the relevance of the socio-spatial approach to the analysis of the functioning and transformation of public spaces in order to increase the level of comfort of living in cities, and smart management of urban development. In this aspect, Kyiv is a good ground for socio-geographical study of various types of public spaces characterized by intensive traditional and specific transformations. The most significant changes are typical for open public spaces. Therefore, in order to understand the factors of contemporary processes in open public spaces, it is necessary to carry out a socio-spatial analysis of a set of parks, public gardens, boulevards, streets, embankments and squares of the capital.

The article presents results of analysis of the peculiarities of Kyiv's open public spaces functioning and transformation in the context of the socio-spatial approach. The analysis revealed that the network of open public spaces in Kyiv corresponds to the stages of the city's territorial development. The most widespread directions of open public spaces transformation in Kyiv are commercialization (functioning of objects providing paid cultural and entertainment services), "beautification" (club design, sculpture installation, renovation of street furniture, registration of thematic zones), (home-type behavior of visitors, the use of home decor items), "europeanization" (designing public spaces based on European urban practices), "ideologization"(commemorative practices through giving relevant names to public spaces and/or establishment of monuments), sacralization (restoration or new construction of temples in parks, squares and gardens), orientation towards the potential consumer (differences in planning design and functions depending on location in the urban planning structure) and "elitization" (allocation of facilities with the club effect). These processes make substantial impact on the intensity of the use of open public spaces in different planning zones, changing their functions and prospects of use.
\end{abstract}

Key words: open public space, socio-spatial approach, spatial analysis, transformations.

DOI: https://doi.org/10.17721/2413-7154/2018.80.18-27

UDC: 911.3:711:304:(477-25)

Received: December 14, 2018.

Accepted: December 27, 2018.

\section{ВІДКРИТІ ПУБЛІЧНІ ПРОСТОРИ КИЄВА В КОНТЕКСТІ СОЦІАЛЬНО-ПРОСТОРОВОГО ПІДХОДУ}

\author{
'Наталія МЕЗЕНЦЕВА, ${ }^{2}$ Марія ПАЛЬЧУК \\ 1,2Київський начіональний університет імені Тараса Шевченка, Україна \\ 'provotarnat@ukr.net, ${ }^{2}$ marialookhere@gmail.com
}

\begin{abstract}
Анотація:Публічніпросториміставизначаютьідентичністьйогомешканців, забезпечують реалізацію комунікаційної функції. Вони постійно змінюються, їм притаманні різноманітні трансформаційні процеси, що відбуваються під впливом різних чинників у розвитку міста. Необхідність пізнання сучасних складних і неоднозначних процесів у містах зумовлює актуальність соціально-просторового підходу до аналізу функціонування і трансформацій публічних просторів з метою підвищення рівня комфортності проживання в містах, розумного управління розвитком міст. В цьому аспекті Київ $\epsilon$ вдалим полігоном для суспільно-географічного дослідження різних типів публічних просторів, які характеризуються інтенсивними традиційними та специфічними трансформаціями. Найістотніших змін зазнають відкриті публічні простори міста. Тому для розуміння чинників сучасних процесів, які відбуваються у відкритих публічних просторах, необхідно здійснити соціально-просторовий аналіз мережі парків, скверів, бульварів, вулиць, набережних та площ столиці.

В статті представлено результати аналізу особливостей функціонування відкритих публічних просторів Києва та їх трансформацій в контексті соціально-просторового підходу.
\end{abstract}

Ключові слова: відкритий публічний простір, соціально-просторовий підхід, просторовий аналіз, трансформації. 
Постановка проблеми. У Києві представлені різні типи публічних просторів: відкриті, закриті, специфічні. До відкритих публічних просторів належать зелені публічні простори (парки культури та відпочинку, районні та спеціалізовані, спортивні парки, сквери, бульвари, дитячі майданчики, прибудинкові території), вулиці, набережні, площі. Закриті публічні простори включають торговорозважальні центри, торгові центри, торговоофісні центри та ринки. Специфічні публічні простори за певних умов можуть мати різну градацію публічності. В Києві вони, наприклад, включають публічні бібліотеки, студентські містечка, автовокзали, залізничні вокзали, культурно-мистецькі та музейні комплекси, палаци та будинки культури тощо. Публічні простори Києва різноманітні за своїми типами та функціями. Вони створювались і формувались у різні періоди, крім того, за різних умов трансформуються. Для них характерні специфічні риси просторової організації.

Соціально-просторовий підхід у дослідженні публічних просторів міст основну увагу концентрує на питаннях дизайну та їхнього використання i передбачає два основні напрями досліджень: перший напрям фокусується на питаннях оптимального проектування і планування публічних просторів; другий напрям основну увагу приділяє соціальним функціям публічних просторів та аналізу наслідків їх функціонування [9]. У межах даного підходу виділяються такі ключові положення: основним просторовим рівнем досліджень $\epsilon$ рівень міських вулиць, як найбільш публічних та найчастіше використовуваних публічних просторів у повсякденному житті міста; соціальна дисфункція публічного простору розглядається не як визначальна його ознака, а як виклик, який необхідно подолати за рахунок поліпшення дизайну; старі форми публічних просторів можуть зникати, а натомість створюються нові, або трансформуватись 3 часом [5].

3 точки зору соціально-просторовому підходу Я. Гейлом була проаналізована динаміка відкритих публічних просторів на прикладі європейських та американських міст [8]. В результаті дослідження він зробив висновок про те, що, що на вулицях міст початку XX століття завжди можна було спостерігати активне життя, що супроводжувалось здійсненням певного виду людської діяльності. Вулиці, площі, ринки, парки - це місця зустрічей, комунікацій, соціалізації, території самовираження. Нині вулиці повні людей, які використовують публічний простір через необхідність, характерні для малорозвинених країн. Для сучасної людини немає необхідності обов'язкового перебування в публічному просторі, тому це є їі вибором за бажанням [8].

На думку Я. Гейла необов'язковий характер більшості заходів публічного життя в сучасних містах визначає високі вимоги до якості відкритих публічних просторів. Вузькі, розділені тротуари, різні перешкоди, бордюри, складні пішохідні переходи вулиць, паркани, відсутність місць для сидіння, гри i тому подібне роблять публічний простір непривабливим. Чим нижча якість конкретного публічного простору, тим менша його популярність, а отже відвідуваність. Таким чином занедбаність публічного простору стає однією 3 причин його втрати. Публіка відмовляється використовувати занедбаний, некомфортний, непривітний простір на користь приватного простору, який подібний до публічного. Під якісними публічними просторами розуміють вдало розташовані із дизайнерським оформленням атрактивні (привітні) простори, які змушують жителів міст частіше залишати їхні заміські будинки $[7,10]$.

Формулювання цілей статті. Враховуючи насиченість Києва різними типами публічних просторів та їх використання мешканцями міста, метою статті визначено аналіз функціонування відкритих публічних просторів Києва для виявлення їх сучасних змін в контексті соціально-просторового підходу.

Таблиияя 1

Розподіл зелених публічних просторів за планувальними зонами Києва

\begin{tabular}{|c|c|c|c|c|c|c|c|}
\hline \multirow[b]{3}{*}{$\begin{array}{c}\text { Планувальна } \\
\text { зона }\end{array}$} & \multicolumn{6}{|c|}{ Площа об’сктів, га } & \multirow{3}{*}{$\begin{array}{l}\text { Частка у } \\
\text { загальній } \\
\text { площі, \% }\end{array}$} \\
\hline & \multicolumn{3}{|c|}{ Парки } & \multirow[b]{2}{*}{ Сквери } & \multirow[b]{2}{*}{ Бульвари } & \multirow[b]{2}{*}{ Всього } & \\
\hline & $\begin{array}{c}\text { культури та } \\
\text { відпочинку, } \\
\text { районні та } \\
\text { спеціалізовані }\end{array}$ & спортивні & Всього & & & & \\
\hline Центральна & 597,5 & 47,7 & 645,2 & 70,87 & 23,7 & 739,77 & 14,0 \\
\hline Південна & 1052,1 & 58,4 & 1110,5 & 40,84 & 15,2 & 1166,54 & 22,1 \\
\hline Західна & 403,3 & 46,9 & 450,2 & 50,81 & 38,0 & 539,01 & 10,2 \\
\hline Північна & 359,3 & 2,6 & 361,9 & 59,23 & 34,4 & 455,53 & 8,6 \\
\hline $\begin{array}{l}\text { Північна } \\
\text { лівобережна }\end{array}$ & 490,8 & 3,0 & 493,8 & 42,57 & 41,2 & 577,57 & 10,9 \\
\hline Східна & 195,0 & 4,7 & 199,7 & 15,23 & 4,1 & 219,03 & 4,1 \\
\hline Долина Дніпра & 1581,3 & 0 & 1581,3 & 0 & 0 & 1581,3 & 30,0 \\
\hline Усього & 4679,3 & 163,3 & 4842,6 & 279,6 & 156,6 & 5278,8 & 100 \\
\hline
\end{tabular}

Складено за даними [1] 
Виклад основного матеріалу. У Києві розміщується 127 парків загальною площею 4679,3 га та 24 спортивних парки площею 163,3 га, 367 скверів загальною площею 279,6 га, 77 бульварів загальною площею 156,6 га. Їх розподіл за планувальними зонами представлений в таблиці 1.

Просторово-часова динаміка розвитку мережі зелених просторів Києва відповідає етапам територіального розвитку міста. Традицію паркового будівництва започаткував митрополит Петро Могила, заклавши перший парк у 1631 році на заміському дворі у Голосієвому. Власне будівництво міських парків розпочалось у XVIII столітті на Печерську. У другій половині XIX ст. мережа парків Києва суттєво збільшилася. На дніпровських схилах були створені парки Володимирська гірка (1850-ті pp.), Шато-де-Флер (1863р.), Маріїнський парк (1874 p.). На той час відвідування парків було платним, а першим безоплатним парком Києва, тобто класичним публічним простором, стала Володимирська гірка.

3 початку 20 ст. на півночі Києва в лісовому масиві Пуща-Водиця розпочалося створення курортної зони, що включала дачне будівництво та однойменний парк. В цей час були відкриті ряд парків, зокрема Пушкінський (1900р.), Політехнічний (1903р.), Зоологічний (1908 р.). До середини 1930-х років у Києві було впорядковано паркову зону вздовж дніпровських схилів та створено у нинішній Національний ботанічний сад імені Миколи Гришка НАН України.

Періодом найінтенсивнішого створення парків в Києві є друга половина 20 ст. В цей час було закладено ряд паркових комплексів (наприклад, Дніпровський, 1945 р.) та парків культури i відпочинку (наприклад, Голосіївський імені М. Рильського та парк Вічної Слави (обидва у 1957 р.), імені М. Фрунзе (1959р.) нині Куренівський парк), Грушки (1971р.), нині парк «Орлятко»). В цей період в Києві були відкриті тематичні парки (наприклад, Перемога (1965р.), Партизанської Слави (1970р.), Печерський ландшафтний парк ім. Є. Вучетича (1978 р., нині Співоче поле)). Унікальними об'єктами не лише міського, але й державного значення стали Виставка досягнень народного господарства (1958 р., нині Національний комплекс «Експоцентр України») та Музей народної архітектури та побуту (1969 р.).

У другій половині 20 ст. здійснювалося озеленення нових масивів Києва - Оболоні, Вигурівщини-Троєщини, Позняків, Виноградаря, Теремків. Характерною рисою для забудови Дарницького, Дніпровського та Оболонського районів столиці стала організація вулиць як бульварів.

Наприкінці XX століття почали формуватися принципово нові ландшафтно-рекреаційні території. Головною їх особливістю $є$ те, що в єдине ціле об'єднуються різноманітні за призначенням об'єкти: житлові будинки, навчальні, розважальні, спортивні, торговельні, бізнесові й адміністративні центри.

(C) Natalia Mezentseva, Maria Palchuk
Розташування зелених публічних просторів у планувальній структурі Києва є нерівномірним. Основними факторами, що зумовлюють потребу у зелених публічних просторах Києва, є такі:

1. Унікальні ландшафти за рахунок елементів рельєфу, гідрологічних об'єктів, представників флори ma фауни, наприклад, парк Володимирська гірка, парковий комплекс Дніпровський, Національний природний парк «Голосіївський». Так, центральна частина паркового комплексу Дніпровський, закладеного у 1945 році, знаходиться на Трухановому острові та включає також Венеціанський і Долобецький острови, урочища Чорторий та Муромець. До комплексу входять Гідропарк та парк «Муромець».

2. Необхідність задоволення суспільних потреб у різних сферах людської життєдіяльності:

- Проведення масових державних або міських заходів, наприклад, на Співочому полі (частина Печерського ландшафтного парку), у Голосіївському парку відпочинку та культури імені М. Т. Рильського, Національному комплексі «Експоцентр України». Так основною функцією Національного комплексу «Експоцентр України» $є$ виставкова діяльність, як інструмент розвитку підприємництва, налагодження міжнародного співробітництва. Одночасно він $€$ центром дозвілля національного рівня, де відбуваються тематичні культурні події (музичні фестивалі, концерти, фестивалі сиру, вина тощо).

- Забезпечення масового відпочинку мешканиів Києва на природі в межах міста, наприклад, у Гідропарку, який був створений у 1965-1968 роках як водно-розважальний комплекс із пляжами та водними атракціонами, закладами ресторанного обслуговування, спортивними площадками. У 2006 році тут було відкрито парк «Київ у мініатюрі».

- Організаиія спортивного відпочинку мешканців міста, проведення спортивних заходів, наприклад, на Льодовому стадіоні, Київському велотреку.

- Щоденні прогулянки поряд із місием проживання. Наприклад, парк «Орлятко» розташовано на території колишніх фруктових садів, які стали планувальним ядром масиву Відрадний. На його території розташована штучна водойма 3 човнами i катамаранами, дитячий майданчик 3 гойдалками, каруселями, готельно-ресторанний комплекс. Створення парку «Відрядний» було пов'язане із будівництвом однойменного житлового масиву.

- Створенні естетичного урбаністичного ландшафту цеентральної частини міста для виконання як функції відпочинку, так і репрезентативної функції міста для туристів, наприклад, Маріїнський парк, парк імені Тараса Шевченка, Золотоворітський сквер.

3. Проведення наукових досліджень, наприклад, Національний ботанічний сад імені Миколи Гришка НАН України, садово-парковий комплекс НАН України «Феофанія», Київський зоологічний парк, Ботанічний сад Національного університету біоресурсів та природокористування, Ботанічний сад імені академіка О. В. Фоміна Київського 
Табличя 2.

Концентрація зелених публічних просторів за планувальними зонами Києва

\begin{tabular}{|l|c|c|c|c|c|}
\hline \multirow{2}{*}{ Планувальна зона } & \multirow{2}{*}{ Площа } & \multirow{2}{*}{$\begin{array}{c}\text { Населення, } \\
\text { тис. осіб }\end{array}$} & га & $\begin{array}{c}\text { \%у у площі } \\
\text { планувальної } \\
\text { зони }\end{array}$ & га на 10 тис. осіб \\
\cline { 4 - 6 } & & 464,6 & 595,9 & 13,2 & 12,8 \\
\hline Центральна & 4512,12 & 421,3 & 2617,0 & 26,8 & 62,1 \\
\hline Південна & 9778,96 & 513,6 & 6115,2 & 50,1 & 119,1 \\
\hline Західна & 12209,3 & 408,8 & 7463,3 & 57,6 & 182,6 \\
\hline Північна & 12961,2 & 715,5 & 10691,1 & 59,2 & 149,4 \\
\hline Північна Лівобережна & 18059,3 & 322,9 & 6655,0 & 49,6 & 206,1 \\
\hline Східна & 13427,11 & - & 8386,0 & 60,6 & - \\
\hline Долина Дніпра & 13833,94 & - & $\mathbf{4 2 5 2 3 , 5}$ & $\mathbf{5 0 , 2}$ & $\mathbf{1 4 9 , 4}$ \\
\hline Усього & $\mathbf{8 4 7 8 1 , 9 3}$ & $\mathbf{2 8 4 6 , 7}$ & &
\end{tabular}

Складено за даними [1]

національного університету імені Тараса Шевченка, Музей народної архітектури та побуту під відкритим небом НДІ етнографічного музеєзнавства НАН України.

4. Створення місиьь пам'яті, наприклад, Національний історико-меморіальний заповідник «Бабин Яр», парк «Кіото», парк культури та відпочинку «Партизанська слава», парк «Перемога», Куренівський парк.

Облаштування території біля громадських ma адміністративних будівель, наприклад, сквер імені Гейдара Алієва, бульвар Верховної Ради.

5. Облаштування територіі 3 метою проведення спеціальних заходів, наприклад, сквер для урочистих церемоній.

6. Необхідність поліпшення екологічної ситуаиії в місті, наприклад, Національний природний парк «Голосіївський», бульвари.

Для аналізу просторової моделі мережі зелених публічних просторів Києва визначено два показники їх концентрації: частка площі зелених просторів у загальній площі планувальної зони міста та відносний показник співвідношення площі зелених просторів на 10 тис. мешканців, які проживають у межах планувальної зони (таблиця 2).

За часткою площі зелених публічних просторів у загальній площі планувальної зони виділено три групи планувальних зон Києва (рис. 1.):

- 3 найвищою часткою (57 - 61 \%): Північна, Північна Лівобережна планувальні зони та Долина Дніпра;

- 3 середньою часткою (49 - 52 \%): Східна та Західна планувальні зони;

- 3 низькою часткою (13 - 27 \%): Центральна та Південна планувальні зони.

За показником площі зелених публічних просторів на 10 тис. мешканців, які проживають у межах планувальної зони, виділено також три групи планувальних зон Києва (рис. 2.):

- 3 найвищою насиченістю (180 - 207 га на 10 тис. осіб): Північна та Східна планувальні зони;

- із середньою насиченістю (119 - 150 га на 10 тис. осіб): Західна та Північна Лівобережна планувальні зони;
- 3 низькою насиченістю $(12$ - 63 га на 10 тис. осіб): Центральна та Південна планувальні зони.

Центральна та Південна планувальні зони мають найнижчі значення обох показників, а Північна планувальна зона - найвищі, Західна планувальна зона характеризується середніми значеннями показників. Зміни груп за значеннями показників характерні для Північної Лівобережної та Східної планувальних зон. У випадку Північної Лівобережної зони позиція за відносним показником співвідношення площі зелених просторів на 10 тис. мешканців нижча, ніж за часткою площі зелених публічних просторів у загальній площі планувальної зони. У випадку Східної планувальної зони навпаки: позиція за відносним показником співвідношення площі зелених просторів на 10 тис. мешканців вища, ніж за часткою площі зелених публічних просторів у загальній площі планувальної зони.

Основу вуличної мережі Києва складають радіальні магістралі - продовження зовнішніх автодорожніх підходів, дві напівкільцеві магістралі на правому березі і ділянки меридіональних магістралей - на лівому. Загальна протяжність вуличної мережі Києва складає 625 км, у тому числі 270, 7 км загальноміського значення та 354,3 км районного значення. Для цього типу публічних просторів столиці характерна конкуренція між пішоходом та автомобілем, між пішоходом та кіосками, літніми терасами кафе $i$ ресторанів. Підтвердженням конкурентної боротьби $є$ неодноразове створення петиції «Повернути пішоходам тротуари», встановлення перешкод для заїзду на тротуар, облаштування спеціальних місць для паркування. Прояв конкуренції між пішоходом та кіосками, літніми терасами кафе i ресторанів виявляється у «окупації» останніми найбільш активних вулиць Києва, які мають туристичну привабливість, та розташовані у діловій частині міста або біля транспортних вузлів (наприклад, вулиць Хрещатик, Попудренка біля станції метро «Чернігівська», проспекту академіка Глушкова біля станції метро «Виставковий Центр»).

У Києві розміщені чотири набережні - Центральна, Дніпровська, Оболонська та 


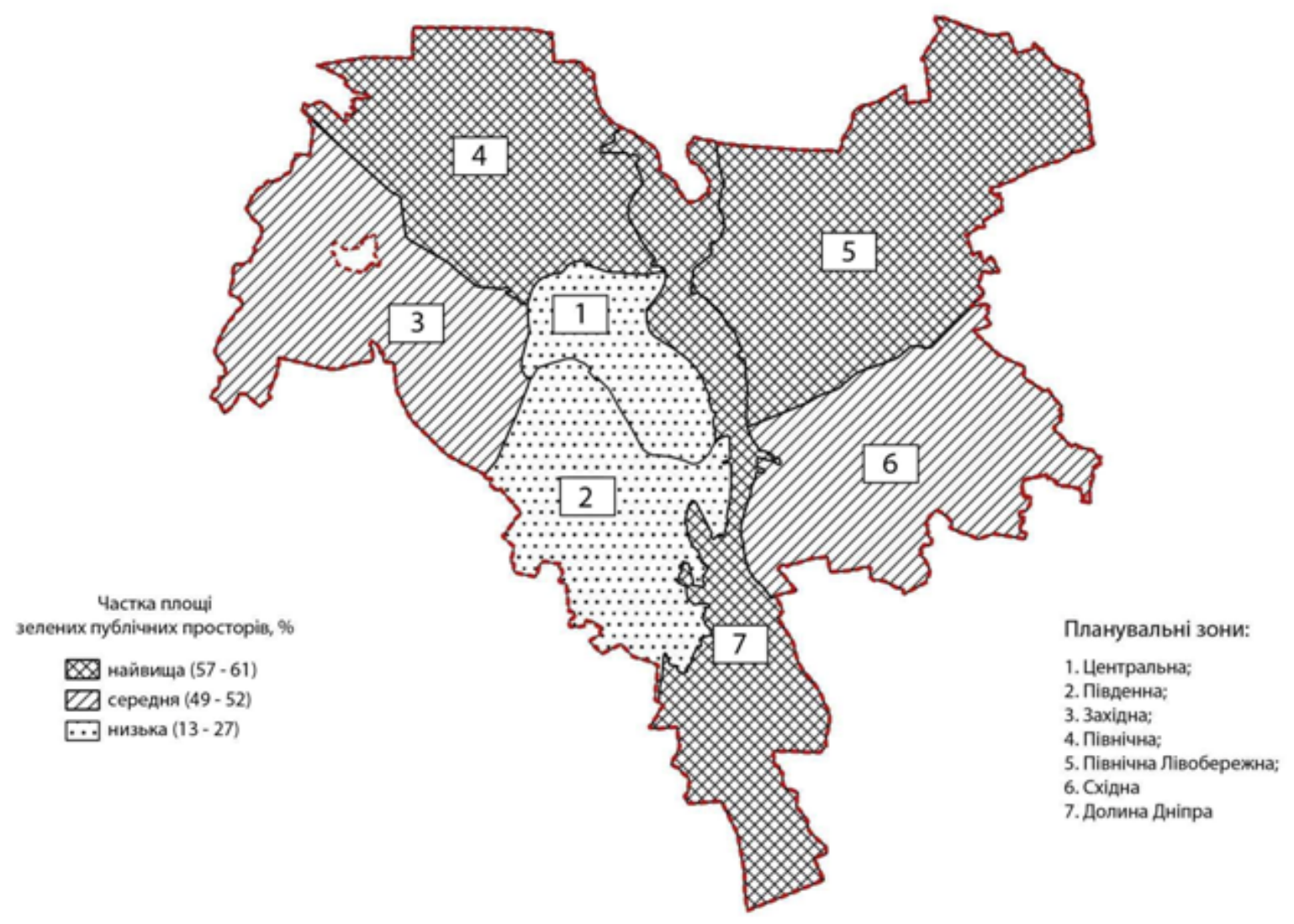

Рисунок 1. Частка площі зелених публічних просторів у загальній площі планувальних зон Києва

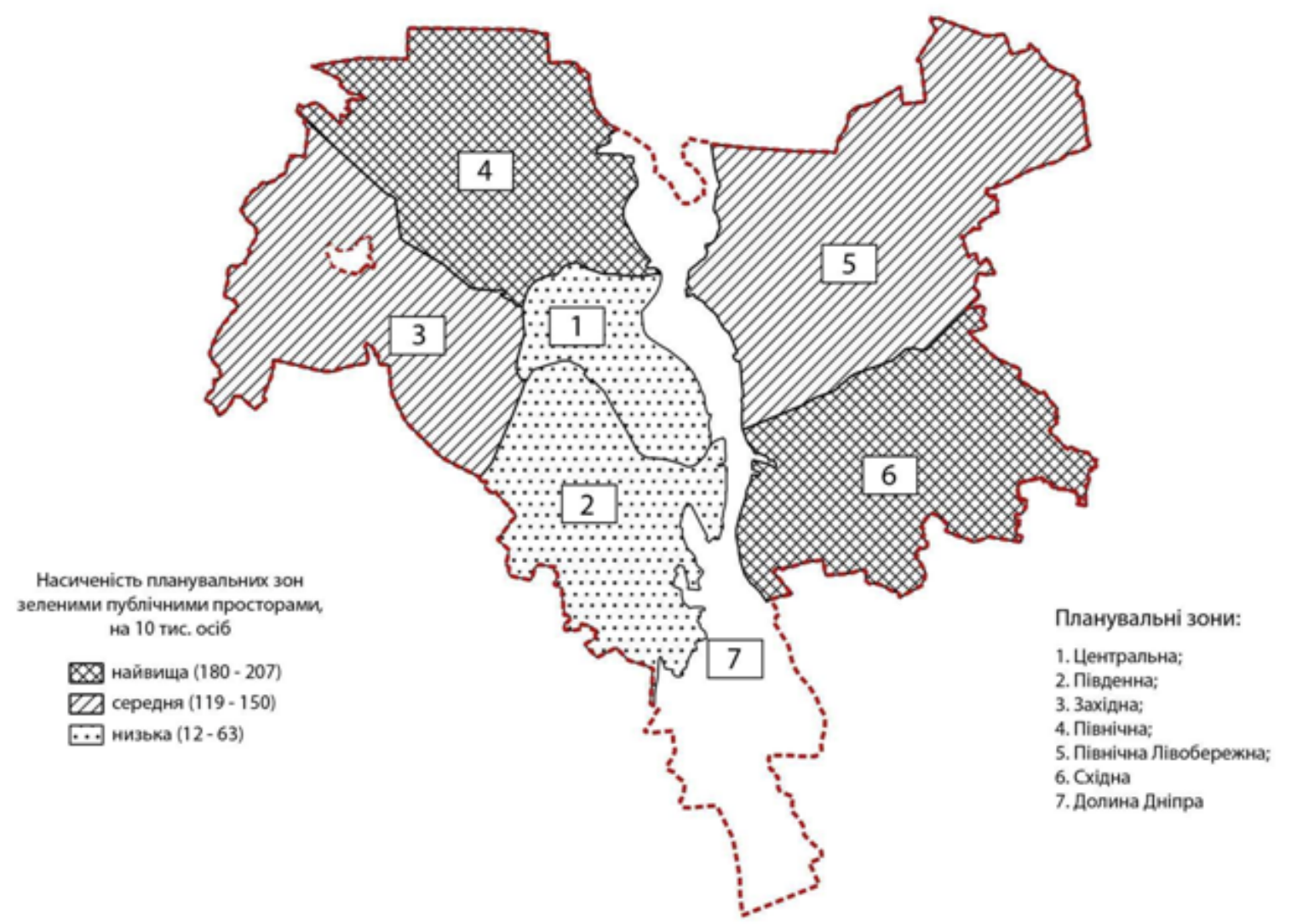

Рисунок 2. Насиченість планувальних зон Києва зеленими публічними просторами, га на 10 тис. осіб 
Русанівська, які як класичні публічні простори облаштовані для прогулянок та відпочинку, створення естетичного урбаністичного ландшафту.

Відкриті публічні простори Києва виконують ряд соціоформуючих функцій:

- комунікаційну: вони є традиційним місцем зустрічей, спілкування, самовираження, проведення святкувань, культурних подій;

- рекреаційну: вони є одними із найпопулярніших місць для відпочинку, прогулянок;

- культурно-розважальну: вони є місцями проведення різноманітних культурно-розважальних заходів;

- політичну: окремі парки, сквери міста є місцем публічних зборів, дебатів, висловлення незгоди, політичних протестів, соціальних рухів;

- формування територіальної ідентичності у мешканців столиці;

- виховну: окремі публічні простори пов'язані із процесом формування національної пам'яті [3].

Аналіз просторово-часової динаміки розвитку мережі відкритих публічних просторів Києва, їх функцій дає підставу виділити певні риси сучасного етапу функціонування цих об'єктів, які детермінують певні трансформації. Аналіз різних аспектів сучасних трансформацій публічних просторів Києва свідчить про те, що вони інтенсивно змінюються, активно використовуються як території політичного протесту, «конфлікту пам'ятей», стають місцями самоорганізації локальних спільнот, комерціалізуються, у т.Ч. в контексті відновлення, реставрації, ревіталізації, розвитку туризму, відповіді на потреби та вподобання міських жителів $[4,6]$.

Для відкритих публічних просторів Києва характерні такі напрями трансформацій:

- комерціалізація - функціонування кафе, ресторанів, кінотеатрів, спортивних закладів та інших об'єктів, які надають платні культурнорозважальні послуги. Наприклад, зона фуд-корту та ресторан «О’Панас» у парку імені Тараса Шевченка, концертний хол «Freedom» на території Куренівського парку, етнографічний комплекс «Мамаєва Слобода» на території парку «Відрадний», кафе «Фонтан» у Золотоворітському сквері, фудзони Центральної та Дніпровської набережних. За динамікою процесу комерціалізації слід виокремити Національний комплекс «Експоцентр України» (ВДНГ), який створювався як об'єкт економічної діяльності і у радянський період вхід до комплексу був платним. На початку 1990-х років у зв'язку 3 економічною кризою та скороченням виставкової діяльності комплекс використовувався переважно як парк для прогулянок, а плату за користування було відмінено. Саме у цей період створились умови для посилення функції його публічності - відкритого простору для всіх. Сучасна нова концепція розвитку Національного комплексу «Експоцентр України» покликана збільшити його рентабельність, проте враховує популярність комплексу як відкритого публічного простору 3 посиленням виставкового та ділового, освітнього та інноваційного кластерів із збереженням рекреаційної функції та лісопаркової зони;

«б’ютифікаиія» - оформлення клумб, встановлення скульптур, вечірне підсвічення, оновлення вуличних меблів, оформлення тематичних зон. Наприклад, оформлення Голосіївського парку відпочинку та культури імені М. Т. Рильського, парку «Наталка», реконструйована Центральна набережна у районі Поштової площі, сквер «Сад каменів» на Оболонській набережній. Важливом елементом, спрямованим на «б’ютифікацію» у столиці є графіті (наприклад, графіті на Центральній набережній);

- доместикація - модель поведінки відвідувачів у публічному просторі ідентична до певних елементів поведінки у приватному просторі. Наприклад, атмосфера перегляду кіно у кінотеатрах під відкритим небом подібна до домашнього перегляду: люди сидять із близькими людьми на пуфах з пледами, беруть їжу, домашніх улюбленців. Такі кіносеанси проходять у парку імені Тараса Шевченка, парку «Наталка», сквері Небесної Сотні. Кожні вихідні впродовж теплого сезону парк «Теремки» використовується мешканцями навколишніх будинків як $\mathrm{BBQ}$ зона 3 моделлю поведінки «у себе на дачі». У парку імені Тараса Шевченка відбуваються турніри 3 настільних ігор, передусім, шахів, притаманні для внутрішніх дворів типових камеральних кварталів «хрущовок»;

- «європеїзація»-загальна тенденція відтворення практик оформлення публічних просторів слідом за парками європейських міст, наприклад, новорічноріздвяні будиночки у парку імені Тараса Шевченка, реконструкція парків 3 копіюванням європейського дизайну вуличних меблів, що характерно для парку «Відрадний», парку «Наталка». Важливим елементом «європеїзації» $€$ використання технічних засобів для підсилення атракції, наприклад, «Великий фонтан» та шість світло-музичних «Малих фонтанів» на Русанівській набережній, облаштування велосипедних доріжок на Микільській Слобідці, проведення культурних заходів, фестивалів, організованих локальною спільнотою на Оболонській набережній;

- «ідеологізаиія» - у радянський період закладена традиція ідеологізації публічних просторів через назви парків, встановлення монументів. 3 початком декомунізації у 2015 році перейменування також містить ідеологічний контекст, наприклад перейменування парку імені генерала Ватутіна в честь Романа Шухевича. У публічних просторах Києва є випадки самочинної декомунізації, наприклад руйнування пам'ятників партійним діячам у парку «Нивки». Сучасний ідеологічний контекст також знаходить своє відображення у облаштуванні парків, наприклад, алея українськогрузинської дружби в парку «Відрадний»;

- сакралізація - відновлення зруйнованих у радянський період церков на території існуючих парків, скверів, або нове будівництво, наприклад, собор у парку «Теремки», храм на місці пам'ятника героям радянського періоду на території скверу по вулиці Глибочицькій напроти кінотеатру 
«Київська Русь», собори на Оболонській та Дніпровській набережних;

- орієнтація на потенційного споживача - відмінність у планувальній організації, функціональному наповненні залежно від розташування у планувальній структурі міста. Функціональне наповнення та оформлення парків у центральній частині міста різноманітніше та якісніше, ніж на периферії. Перш за все, це зумовлено вимогами споживачів: джентрифікована центральна планувальна зона має вищі запити, ніж міська периферія;

- «елітизація» - розміщення об'єктів, які втілюють ефект клубу, наприклад, яхт-клуби вздовж Дніпровської набережної, гольф поле на Оболонській набережній.

Для деяких відкритих публічних просторів Києва характерний процес повільного скорочення їх функцій та зменшення попиту на використання порівняно із попередніми періодами їх функціонування. Це стосується, наприклад, парку «Нивки», Куренівського парку, бульвару Тараса Шевченка.

У ході проведення спостережень за відкритими публічнимипросторамиміста Києва, було виявлено, що частина відкритих публічних просторів має платне використання і це обмежує їх доступність. Передусім, це ботанічні парки, ландшафтні парки, які мають наукове призначення та перебувають у підпорядкуванні відповідних установ (наприклад, парк «Феофанія», Національний ботанічний сад імені М. М. Гришка НАН України, Київський зоологічний парк, Національний музей архітектури i побуту України). При цьому слід виокремити Ботанічний сад НУБіП та Ботанічний сад імені академіка О. В. Фоміна Київського національного університету імені Тараса Шевченка, де не зважаючи на відомче підпорядкування, використання публічних просторів є безоплатним. Щодо спортивних парків, то в Києві виявлена аналогічна ситуація: використання деяких парків $є$ платним (наприклад, НСК «Олімпійський», стадіон «Динамо» імені Валерія Лобановського) а інших - безоплатним (наприклад, Льодовий стадіон, велотрек «Авангард»).

Окремим видом відкритих публічних просторів Києва є міські площі, яких у Києві налічується 54. Основним фактором, який визначає розміщення площ Києва є архітектурна концепція планувальної організації конкретної території 3 урахуванням таких природних факторів як рельєф та геологічна будова. Мета розміщення кожної площі відображена у їі функціональному типі. Функціональні типи площ Києва представлені у таблиці 3.

Найпоширенішим функціональним типом площ у Києві є транспортні площі - 34 об'єкти. Такі площі не можуть виконувати функції міських публічних просторів, а $\epsilon$ виключно транспортно-інженерними об'єктами. У Північній Лівобережній та Західній планувальних зонах розташовані виключно транспортні площі. У
Східній, Південній та Північній планувальних зонах наявні по одній площі, які можуть виконувати функції публічного простору. Лише окремі площі Центральної планувальної зони $\epsilon$ публічними просторами - ринкові, головні, перед громадсько-адміністративними будівлями i спорудами, вокзальна, багатофункціонального транспортного вузла.

Виникнення, перепланування, зміни функціональних типів площ, їх зникнення визначаються містобудівним освоєнням території Києва. Функціональний тип окремих площ змінювався впродовж розвитку планувальної структури Києва, а також у зв'язку із розташуванням у їх межах об'єктів, які надають площам ознак публічного простору.

Для Бессарабської площі характерне поєднання історичної ринкової функції із порівняно новою транспортною. Святошинська площа до забудови новою житловою забудовою у 1980-х роках була типовою ринковою площею та мала назву Базарна, проте сьогодні $є$ типовою транспортною площею. Забудова Володимирської площі та площі Глінки призвела до їх зникнення. 3 часом у Києві відбулася зміна функціонального типу Деміївської площі 3 ринкової на транспортну.

Серед площ, в межах яких розташовані об'єкти, які надають площам ознак публічного простору - Бессарабська, Кривоноса Петра, Севастопольська. у їх межах розміщені громадські об'єкти (ТРЦ «Арена», музей, галерея, кінотеатр). У цьому випадку основною функцією площі залишається транспортна, а функції публічних просторів виконують громадські об'єкти.

Такі транспортні площі як Либідська, Житньоторзька, Валерія Марченка, Львівська, Петропавлівська мають облаштовані сквери. Наявність скверів дозволяє визначити такі локації як публічні простори. Для зелених просторів на площах Валерія Марченка та Петропавлівській характерним $\epsilon$ процес «сакралізації».

Цікавими публічними просторами $\epsilon$ транспортні площі, на яких розміщено монументальні об’єкти. Наприклад, площа Перемоги - це територія історичної ринкової площі (Галицький базар, пізніше Сврейський базар), на якій до 1934 року розташовувався храм, на місці якого пізніше збудували цирк. Історично це місце виконувало функцію ринкової площі. Сьогодні площа Перемоги не є місцем для зібрань, спілкування, відпочинку, це фактично транспортна розв'язка. Але наявність на ній монументу містугерою Києву несе певну комунікативну функцію, тобто відбувається передача інформації від влади, ідеології до публіки.

Софіївська та Михайлівська площі планувались як площі перед відповідними сакральними спорудами (сучасний функціональний тип перед громадсько-адміністративними будівлями i спорудам), але у процесі історичного розвитку Києва трансформувались у загальноміські головні площі. 
Функціональні типи площ за планувальними зонами Києва

\begin{tabular}{|c|c|c|}
\hline Планувальна зона & Функціональний тип & Площі \\
\hline \multirow{7}{*}{ Центральна } & Ринкові & Лук'янівська, Печерська \\
\hline & Головні & $\begin{array}{l}\text { Контрактова, Михайлівська, Майдан Незалежності, } \\
\text { Софіївська }\end{array}$ \\
\hline & Транспортні & $\begin{array}{l}\text { Андрія Первозванного, Бессарабська, Героїв } \\
\text { Великої Вітчизняної Війни, Либідська, Європейська, } \\
\text { Житньоторзька, Львівська, Перемоги, Льва Толстого }\end{array}$ \\
\hline & $\begin{array}{l}\text { Перед громадсько- } \\
\text { адміністративними } \\
\text { будівлями і спорудами }\end{array}$ & $\begin{array}{l}\text { Арсенальна, Ботанічна, Конституції, Лесі Українки, } \\
\text { Слави, Спортивна, Івана Франка }\end{array}$ \\
\hline & Вокзальні & Вокзальна \\
\hline & $\begin{array}{l}\text { Багатофункціонального } \\
\text { транспортного вузла }\end{array}$ & Поштова \\
\hline & Кількість площ & 24 \\
\hline \multirow{3}{*}{ Південна } & Транспортні & $\begin{array}{l}\text { Амурська, Голосіївська, Космонавтів, Кривоноса } \\
\text { Петра, Деміївська, Одеська, Севастопольська }\end{array}$ \\
\hline & $\begin{array}{l}\text { Перед громадсько- } \\
\text { адміністративними } \\
\text { будівлями і спорудами }\end{array}$ & Солом’янська \\
\hline & Передзаводські & Співака Михайла \\
\hline \multirow{3}{*}{ Західна } & Кількість площ & 9 \\
\hline & Транспортні & Героїв Бреста, Святошинська \\
\hline & Кількість площ & $2+2+2$ \\
\hline \multirow{3}{*}{ Північна } & $\begin{array}{l}\text { Перед громадсько- } \\
\text { адміністративними } \\
\text { будівлями і спорудами }\end{array}$ & Червона Пресня \\
\hline & Транспортні & $\begin{array}{l}\text { Гостомельська, Оболонська, Загороднього Михайла, } \\
\text { Валерія Марченка, Мінська, Петропавлівська, } \\
\text { Сантьяго-де-Чилі, Тульська, Тараса Шевченка, } \\
\text { Леоніда Телятникова }\end{array}$ \\
\hline & Кількість площ & 11 \\
\hline \multirow[t]{2}{*}{ Північна Лівобережна } & Транспортні & $\begin{array}{l}\text { Анкари, Волгоградська, Керченська, Дарницька, } \\
\text { Пантелеймона Куліша, Новоросійська }\end{array}$ \\
\hline & Кількість площ & 6 \\
\hline \multirow{3}{*}{ Східна } & Вокзальні & Привокзальна \\
\hline & Транспортні & Харківська \\
\hline & Кількість площ & 2 \\
\hline
\end{tabular}

Складено за даними [2]

Як і для всіх відкритих публічних просторів у сучасному місті для площ характерна комерціалізація. Висока концентрація потенційних споживачів на вокзальних площах, а також потенційно тривалий час їх перебування зумовлює розміщення комерційних об'єктів (кіоски 3 сувенірами, подарунками, фаст-фуди). Істотний вплив на посилення атракції Спортивної площі здійснило будівництво ТРЦ «Gulliver». Постійно діючі ятки iз сувенірами, кафе, зони фастфуду представлені на Майдані Незалежності та Контрактовій площі. «Європеїзація» проявляється у розміщенні типових для європейських міст новорічних та різдвяних містечок на Софіївській, Михайлівській та Контрактовій площах. Прикладами процесу «б'ютифікації» є площа Івана Франка - облаштування клумб, розміщення вуличних меблів, скульптур, які виконані у єдиному стилі. «Ресакралізація» характерна для Михайлівської площі - відбудова Михайлівського Золотоверхого монастиря.

Площі Лесі Українки та Конституційна розташовані перед будівлями, у яких розміщені державні органи влади в Україні. Ці площі $\epsilon$ місцем не лише відпочинку працівників, містян, туристів, а й місцем проведення протестів. Саме тому по відношенню до цих публічних просторів вжиті превентивні заходи, такі як встановлення паркану, здійснення охорони. Ці заходи обмежують публічність таких просторів.

Головні площі виконують важливу для демократичної політичної системи функцію політичну у формі протестів. Масові протести національного рівня відбуваються на головній 
площі міста - Майдані Незалежності. У період Радянського Союзу Майдан Незалежності мав декілька назв (Радянська площа, площа імені Калініна, площа Жовтневої революції) та виконував репрезентативну функцію: демонстрація могутності соціалістичної республіки в архітектурних формах, проведення військових парадів та організованих демонстрацій. Першим протестом, який відкрив еру незаангажованої ідеологією публічності простору, була «Революція на граніті» 1990-го року.

На можливу ймовірність прогресивного розвитку площі як публічного простору 3 усіма трансформаціями впливає розташування у планувальній структурі Києва. Так, наприклад, розташування Майдану Незалежності, Поштової та Софіївської площ у Центральній планувальній зоні позитивно вплинуло на їх розвиток, а розміщення Солом'янської площі, площі Співака Михайла та інших у Південній та Північній планувальних зонах не вирізняється переважанням позитивних ознак у їх розвитку.

Висновки. В результаті проведеного аналізу виявлено, що мережа відкритих публічних просторів Києва відповідає етапам територіального розвитку міста. Визначено, що потребу у зелених публічних просторах Києва зумовлюють необхідність: проведення масових державних або міських заходів: забезпечення масового відпочинку мешканців Києва на природі в межах міста; забезпечення щоденного відпочинку киян поряд із місцем проживання; створення місць пам'яті; облаштування території; поліпшення екологічної ситуації в місті. Виділено найпоширеніші напрями трансформацій відкритих публічних просторів Києва: комерціалізацію (функціонування об'єктів, які надають платні культурно-розважальні послуги), «б'ютифікацію» (оформлення клумб, встановлення скульптур, оновлення вуличних меблів, оформлення тематичних зон), доместикацію (запровадження моделі поведінки відвідувачів ідентичної до певних елементів поведінки у приватному просторі, використання предметів домашнього декору), «європеїзацію» (відтворення практик оформлення публічних просторів за прикладом європейських міст), «ідеологізацію» (через назви публічних просторів, встановлення монументів), сакралізацію (відновлення зруйнованих чи нове будівництво храмів на території парків, скверів, площ), орієнтацію на потенційного споживача (відмінність у планувальній організації та функціональному наповненні залежно від розташування у планувальній структурі міста) та «елітизацію» (розміщення об'єктів 3 ефектом клубу). Вони здійснюють суттєвий вплив на інтенсивність використання відкритих публічних просторів у різних планувальних зонах Києва, зміни їх функцій та перспективи використання.

\section{References:}

1. General'nij plan m. Kiêva. Osnovnì položennâ [Kyiv General Plan. Key provisions]. Kyiv: Department for Urban Development and Architecture of the Kyiv City State Administration, Municipal Institution "Institute for Kyiv General Plan", 2015, 103 p. (In Ukrainian).

2. General'nij plan mista Kiêva na perìd do 2020 r. Osnovni položennâ [Kyiv General Plan for 2020. Key provisions]. Kyiv: Kyiv City State Administration, JSC "Kyivproject", Municipal Institution "Institute for Kyiv General Plan", 2001, 69 p. (In Ukrainian).

3. Mezentsev K., Mezentseva N. Publičnì prostori Kiêva: zabezpečenìst' naselennâ ta sučasna transformaciâ [Public spaces of Kyiv: accessibility to residents and modern transformation], Journal of Human Geography, 2011, Vol. 11(2), pp. 39-47. (In Ukrainian).

4. Mezentsev K., Mezentseva N. Sučasnì transformaciï publičnih prostorìv Kiêva: peredumovi, proâv ta specifika [Modern transformations of Kyiv's public spaces: preconditions, manifestation and specifics]. Journal of Human Geography, 2017, Vol. 22(1), pp. 39-46. (In Ukrainian).

5. Mezentseva N., Palchuk M. Publičnì prostori mìst: osmislennâ čerez prizmu zarubìžnogo diskursu [Urban public spaces: understanding through the prism of foreign discourse]. Ekonomichna ta Sotsialna Geografiya, 2016, Vol. 76, pp. 19-26. (In Ukrainian).

6. Urbanistična Ukraïna: v epicentri prostorovih zmin [Urban Ukraine: in the epicentre of spatial changes].

[Eds.: K. Mezentsev, Ya. Oliynyk, N. Mezentseva], Kyiv: Fenix, 2017, 438 p. (In Ukrainian).

7. Common ground? Readings and Reflections on Public Space [Eds.: Z. Neal, A. Orum]. New York : Routledge, 2009,240 p.

8. Gehl, J. New City Spaces. Copenhagen: The Danish Architectural Press, 2001, 263 p.

9. Neal, Z. Seeking common ground: three perspectives on public space. Urban Design and Planning, 2010, Vol. 163, No. 2, pp. 59-66.

10. Public spaces for a changing public life [Electronic source]. Режим доступу: https://www.openspace.eca. ed.ac.uk

\section{Список використаних джерел:}

1. Генеральний план м. Києва. Основні положення / Департамент містобудування та архітектури КМДА, КО «Інститут генерального плану м. Києва». - К., 2015. - 103 с. 
2. Генеральний план міста Києва на період до 2020 р. Основні положення / КМДА, АТ «Київпроект», Інститут «Київгенплан». - К., 2001. - 69 с.

3. Мезенцев К.В. Публічні простори Києва: забезпеченість населення та сучасна трансформація / К.В. Мезенцев, Н.І. Мезенцева // Часопис соціально-економічної географії. - 2011. - Вип. 11 (2). - С.39-47.

4. Мезенцев К.В. Сучасні трансформації публічних просторів Києва: передумови, прояв та специфіка / К. В. Мезенцев, Н.І. Мезенцева // Часопис соціально-економічної географії. - 2017. - Вип. 22(1). - 39-46.

5. Мезенцева Н.І. Публічні простори міст: осмислення через призму зарубіжного дискурсу / Н. I. Мезенцева, М. В. Пальчук // Економічна та соціальна географія. - 2016. - Вип. 76. - С. 19-26.

6. Урбаністична Україна: в епіцентрі просторових змін. Монографія. За ред. К.Мезенцева, Я.Олійника, Н.Мезенцевої. - К.: Фенікс, 2017. - 438 с.

7. Common ground? Readings and Reflections on Public Space [Editors: Z. Neal, A. Orum]. New York : Routledge, 2009, 240 p.

8. Gehl Jan. New City Spaces / J. Gehl. Copenhagen: The Danish Architectural Press, 2001, 263 p.

9. Neal Z. Seeking common ground: three perspectives on public space / Z. Neal // Urban Design and Planning. - 2010. - Vol. 163. - No. 2. - Pp. 59-66.

10. Public spaces for a changing public life [Електронний pecypc]. Режим доступу: https://www.openspace. eca.ed.ac.uk 